\title{
Destination Quality Perception in the Context of Different Behavioural Characteristics of Visitors
}

\section{Kateřina Ryglová1 / Ida Vajčnerová ${ }^{2}$ / Jakub Šácha ${ }^{3}$}

e-mail: katerina.ryglova@email.cz

${ }^{1}$ Department of Marketing and Trade, Faculty of Business and Economics, Mendel University in Brno, Brno, Czech Republic

${ }^{2}$ Department of Management, Faculty of Business and Economics, Mendel University in Brno, Brno, Czech Republic

${ }^{3}$ Department of Statistics and Operation Analysis, Faculty of Business and Economics, Mendel University in Brno, Brno, Czech Republic

Ryglová, K., Vajčnerová, I., \& Šácha, J. (2016). Destination Quality Perception in the Context of Different Behavioural Characteristics of Visitors. Czech Journal of Tourism, 5(1), 5-20. DOI: 10.1515/cjot-2016-0001

\begin{abstract}
Visitors' perceptions of the quality of a tourism destination are fundamental for effective destination management and marketing. This paper deals with the topic of destination quality from the viewpoint of demand, i.e. from the viewpoint of a destination visitor. The results of perceiving the destination quality partial factors in the context of different behavioural characteristics of a visitor are presented, particularly, the way how spending and organizing a holiday influences the perception of destination quality factors (Kruskal-Wallis test). The research nineteen factors were designed on the basis of contemporary theories and on qualitative research. Some important quality aspects related to tourism were identified and assessed for the Czech population. The primary data were obtained through a questionnaire survey with quota sampling $(n=1097)$. The dependence of destination quality perception on the way of spending the holiday was revealed in the case of 8 factors (e.g., Availability of transportation to the destination, Availability and quality of information; Additional infrastructure, Sense of security, Destination cleanliness, Uniqueness of destination, Price level in the destination, Cultural monuments). The significant differences identified among various groups of respondents are described in detail in this study. The research findings contribute to better understanding of the behavioural mechanism and can be used by destination managers to design communication strategies for different segments of consumers for individual destinations to improve their competiveness.
\end{abstract}

\section{Keywords}

tourism; destination quality; factors of destination quality; visitors' perception; behavioural aspects

JEL classification: M310 


\section{Introduction}

Tourism is a very interesting and perspective branch of the service sector for the Czech Republic. 22,200,880 foreign tourists stayed overnight in the Czech Republic in 2014, whereas in 2015 this number increased by over 1 million (MMR, 2015). The share of tourism in GDP in the Czech Republic has recently been just under 3\%, which is similar to the value of GDP for Sweden, the Netherlands and Germany. The share of tourism in the Czech Republic in total employment is slightly above $4.5 \%$ and the total number of people employed in tourism is about 230,000 people - approximately $80 \%$ of them are employees and $20 \%$ are entrepreneurs. In the period of global competition, when the whole range of substitution products is offered, quality is becoming a strong competitive advantage. Especially in European destinations that cannot compete with exotic destinations in developing countries in terms of their service prices, the high quality accompanied with the differentiation of the offer is considered to be a decisive factor of the competitive fight. In spite of this fact, the service quality, especially its very different level in regions, is considered to be the weakness of tourism development in the Czech Republic. For this reason, the quality is nowadays one of the priorities of the Conception of State Politics for Tourism for the Period of 2014-2020. In this environment the outcomes of marketing research could help increase the quality of the offered services in the field of tourism. The research discussed in this article relates to the perception of the destination quality factors by visitors, which can be considered as a starting point of effective quality management and further quality research.

The purpose of this research is to explore the relationship between perceptions of destination quality factors and selected different behavioural characteristics of visitors. Baker and Crompton (2000) examined the relationship between quality, satisfaction and behavioural intentions and confirmed the hypothesis that perceived quality has a major influence on subsequent customer behaviour. Previous studies in tourism presented some results showing different quality perception in the context of different visitors' characteristics (e.g. Collins \& Tisdell, 2002; Firestone \& Shelton, 1994; Mottiar \& Quinn, 2003; Meng et al., 2008). In the Czech Republic there is research that focuses on the typology of visitors in tourism (Š́mová, 2009; Vondruška, 2006), but the analysis of different perceptions of destination quality in case of various visitor segments has not been dealt with yet. The authors of this study want to verify the assumption whether in the Czech Republic various visitor segments also perceive the destination quality factors in different ways and they want to identify these differently perceived factors.

The purpose of this article is to present the results of the research exploring the identification of the significance of individual factors determining the perception of destination quality in relation to different groups of visitors according to their dissimilar behavioural characteristics in the Czech Republic. 


\section{Theoretical basis}

According to the United Nations World Tourism Organisation (UNWTO, 2003), a tourism destination is defined as "a place with suitable attractions together with tourism facilities and services that a tourism participant has chosen for his or her visit ". One of the most frequent quoted definitions of the destination is the definition by Bieger (1996) who considers the destination to be "a geographical area that a client chooses as a target of his or her journey". According to Cho (2000), the destination is "a target place of potential clients who see the area from their points of view in relation to the content (product) and location (region) with the purpose to satisfy their needs and requirements during their stays in the target area.

Determining and then evaluating the destination quality in the context of tourism development is not an easy issue, which is confirmed by different approaches towards these terms in scientific literature. This fact is given by not only the high level of the product/destination complexity but especially by the high level of subjectivity during quality evaluation. Consumer typologies have been the research issue in tourism since the 1970s and they represent the effort of generalizing the consumer segmentation in tourism. A large number of tourist typologies is described in professional literature (e.g. Cohen, 1972, 1979; Hsieh et al., 1997; Decrop \& Snelders, 2005).

The characteristic components of destinations - Attraction, Amenities, Ancillary Services, Accessibility, Available Packet, Activities (Buhalis, 2003) - indicate that although the service quality is primarily evaluated only in terms of functional quality, using SERVQUAL, the destination assessment by technical quality aspects (the range of attractions and services) is necessary as well (Grönroos, 2007). Middleton and Clarke (2001) argue that the destination is made up of five components, three of which are the same as the components used by Buhalis (2013) (Attraction, Amenities, Accessibility) and the other two components are the image and perception of a destination and the price.

From the marketing point of view, the destination is a complex product of tourism that has to have necessary quality and has to be managed strategically. Therefore, managing the quality destination can be approached through the mediation of a client/visitor when on the basis of his or her needs and requirements the offer is subsequently formed and modified. In this case, it is important to determine crucial factors that influence tourism destination quality evaluation. These factors can then be used as a tool for evaluating destination quality through a client/visitor's satisfaction. For example, the measurement of the overall satisfaction with a destination according to Campo-Martãnez and Garau-Vadell (2010) was based on the identification and assessment of key variables.

The methods that enable to evaluate quality in tourism from the customers' perspective by means of analysing customer perception are, for instance, IPA, SERVQUAL or PFI. IPA (Importance-performance analysis) introduced by Martilla and James (1977) is a tool for identifying the relative importance and performance of individual factors that have an impact on the monitored quality. SERVQUAL enables to evaluate quality on the basis of the difference between the consumer's expectation and perception. As the basic 
dimensions of service quality from the customer's point of view, it evaluates the reliability, assurance, responsiveness, empathy and tangibles of the service (Parasuraman et al., 1988). PFI (Priorities for Improvement; Hill at al., 2003) is based on the identification of customers' requirements and wishes. Eklof and Westlund (1998) analyse the topic of Customer Satisfaction Index in the context of its role in the quality management.

Some authors have approached service quality and consumer satisfaction as being synonymous (Crompton \& Love, 1995; Otto \& Ritchie, 1995) or have narrowed its distinction (Spreng et al., 1996). Recently, the majority of researchers have confirmed that quality is a predictor of satisfaction (Fornell et al., 1996; Kozak \& Rimmington, 2000). The empirical analysis carried out on a sample of visitors of an interpretation centre confirms that the perceived quality is a direct determinant of satisfaction (Campo-Martãnez \& Garau-Vadell, 2010; de Rojas \& Camarero, 2008).

The area of destination quality is perceived differently not only by visitors or potential visitors, but by entrepreneurs, local autonomies, destination managers and local inhabitants who have an impact on creating the image of the given area. Theoretical formulations for the destination quality management (DQM) are included in the publication written by Woods and Deegan (2003) who analysed different approaches to quality models as SERVQUAL, Gap model, Kano model, and EFQM model. On the basis of their findings, the principles for the theoretical concept of DQM originated. These are the principles which are based on the tenets of the necessity to meet the basic standards of destination customers' minimum needs. Currently, there are only a few studies that can be found that deal with evaluating the destination quality as a complex product of tourism (e.g. Krešić, 2008; Xielong, 2011; Žabkar et al., 2010).

\section{Methodology}

In order to reach the stated targets, i.e., to determine the main factors of tourism destination quality and to reveal its significance for a visitor to the destination, a questionnaire survey among the Czech Republic population was used. The sample of 1,097 respondents was set as a quota sampling (gender and age); detailed sample structure is described in Table 1 below. Personal and electronic data were collected during the spring of 2015. The questions in the questionnaire which were aimed to reveal the significance of individual quality factors perceived by the visitor were formulated on a five-point scale, where number 5 represented the high/extraordinary significance of the evaluated factor. 
Table 1 The structure of research sample

\begin{tabular}{llllr}
\hline Number of respondents & 1097 & & & \\
\hline Characteristics & Sample structure & & & \\
\hline Gender & Male & $48.6 \%$ & Female & $51.4 \%$ \\
Age & $18-23$ years & $17.2 \%$ & $51-60$ years & $15.8 \%$ \\
& $24-30$ years & $16.9 \%$ & $61-70$ years & $12.6 \%$ \\
& $31-40$ years & $16.5 \%$ & 71 and more & $4.5 \%$ \\
Place of residence & $41-50$ years & $16.6 \%$ & & \\
& & & & $46.2 \%$ \\
Education & city/town & $53.8 \%$ & village & $34.8 \%$ \\
& & & & \\
& Primary & $3.9 \%$ & higher & \\
& Secondary & $61.3 \%$ & & $2.4 \%$ \\
& & & & \\
\hline
\end{tabular}

Source: own research (2015)

The factors that are evaluated in the questionnaire were formulated on the basis of the original research on the quality components of the destination (Buhalis, 2003; Middleton \& Clarke, 2001) and on the basis of the theoretical formulations for the destination quality management presented by Woods and Deegan (2003). The research factors equally consider the functional and technical quality of services (Grönroos, 2007) and are stipulated in order to suit all types of destinations.

Kruskal-Wallis test was used in order to find out whether the evaluation of the individual factors significance is dependent on the chosen behavioural characteristics or not. It is a non-parametric analogue of the single factor analysis of variance that could not be used because of non-normal data. This test verifies the null hypothesis that the evaluation of the examined factor has the same distribution for each group. The rejection of this hypothesis means that the differences are statistically significant, i.e., the dependence of the examined factor on respondents' behavioural characteristic was proven.

The frequently used behavioural segmentation criterion (e.g. Cohen, 1972, 1979; Hsieh et al., 1992) is used in this research; specifically, the way of organizing and spending holidays that is adapted to the specifications of a Czech client/visitor: 
- The preferred way of spending the holiday:

- How actively it is spent:

- tour/sightseeing holiday (tour aimed at getting to know new places, tourist searches for authentic experience; corresponding with Experiential tourist (Cohen, 1979)),

- holiday stay/hotel-based (tourist stays in one destination/in one hotel) - active; corresponding with Recreational tourist in Cohen (1979),

- holiday stay/hotel-based - relaxation (corresponding with beach/resort seeker (Baloglu \& Uysal, 1996)).

- Who it is spent with (corresponding to family life cycle (Fodness, 1992)):

- without children, with a partner only,

- without children, with friends only,

- without children, with a partner as well as friends,

- at least one child of a pre-school age,

- with school children only.

- The organization of the holiday with various levels of using tour operators or travel agency services:

- Clients who use the services of travel agencies or tour operators when organizing their journey.

- Clients using the agent's services partly for partial journey elements only.

- Clients who do not use tour operators' services.

\section{Results and discussion}

In Table 2 below the order of the quality factors is shown according to the average evaluation of all 1,097 responders. Then there is the standard deviation for individual factors. Afterwards, the dependency of individual factors evaluation on the responder's behavioural characteristics was explored - these characteristics are related to the preferred way of spending the holiday (particularly how actively it is spent; who it is spent with) and with the organization of the holiday with various levels of using tour operators' services. On 5\% significance level, the dependency of destination quality perception on the way of spending the holiday (how, who with) was proven in case of 3 factors (Availability of transportation to the destination, Availability and quality of information; Additional infrastructure); on $10 \%$ significance level, this dependency was proven in case of 8 factors.

For evaluating the dependency, Kruskal-Wallis test was used; it is a nonparametric analogy of the one-factor dispersion analysis that could not be used due to the abnormality of the data. This test is used to verify the null hypothesis that the evaluation of the research factor has the same distribution for all alternatives of replies to the compared question. Rejecting this hypothesis means that the differences are statistically significant, i.e., that the dependency of the research factor evaluation on behavioural characteristics 
was proven. The results of Kruskal-Wallis test are presented in the last three columns of Table 2; P-value of the test is shown in the first part of each column and the verbal evaluation of the test is in the second part of the column. The result YES+ means that the dependency was proven on $5 \%$ significance level, the result YES means that the dependency was proven on $10 \%$ significance level only and the result NO means that the dependency of the result on the research behavioural characteristics was not proven.

In the following Tables 3, 4 and 5 the dependencies of the quality factor evaluations on the behavioural characteristics mentioned in the methodology part are analysed. For individual variations of behavioural characteristics the average evaluations for each quality factor were calculated and for the factors with statistically significant differences the variation of the answer with the highest average evaluation is highlighted, i.e. the respondent attributes the highest importance to this factor when evaluating destination quality.

In Table 3 the evaluation of the quality perception dependency on the preferred way/ type of holiday from the viewpoint of the visitor's activity (how) is described: tour/ sightseeing holiday, holiday stay/hotel-based - active, holiday stay/hotel-based - relaxation. The dependency of the evaluation of the importance of the quality factors was proven in case of nearly $68 \%$ research quality factors (13 out of 19), which corresponds to the initial expectation, i.e. the visitor's priorities will be affected by holiday activities to a great extent.

People who prefer the tour/sightseeing type of holiday consider the following as the most important quality attributes of a destination: F1 Natural attractions (e.g. conditions of natural character such as mountains, water, caves, natural reservations), F2 Cultural monuments (e.g. castles, chateaus, galleries, technical sights, UNESCO sights, historical town centres), F8 Availability and quality of information (e.g. tourist information centres, orientation boards), F17 Uniqueness of the destination (e.g. the uniqueness of the locality, local products), F19 Respecting the sustainable development of the destination (e.g. the concordance of infrastructure construction with the natural space of the destination, cultural and natural heritage protection, local entrepreneurs support, involving local inhabitants and businessmen into the area development).

The group of factors for which the dependency was also statistically significant and which are prior for the visitors selecting relaxation character of their holiday also include: F14 Sense of security, F15 Destination cleanliness, F12 Level of prices of services and goods in the destination, F7 Local transportation, F3 Accommodation, F4 Food, F13 Level of personnel quality in tourism services. The factor Sense of security contains security issues of the destination, which include not only local security of the place but also security in form of health risks (e.g. infectious diseases, drinking water, and health system), safe natural conditions (e.g. earthquakes, floods), or a crime rate etc. The factor Destination cleanliness contains clean natural environment (water for swimming, air), way of dealing with local waste, cleanliness of public places, or urban cleanliness.

On the other hand, Factor F18 Additional infrastructure (e.g. sports equipment rental shops, cycle paths, cross-country ski trails, aqua parks, entertainment centres) was the only one to reach the highest evaluation score when people preferred the hotel-based ac- 


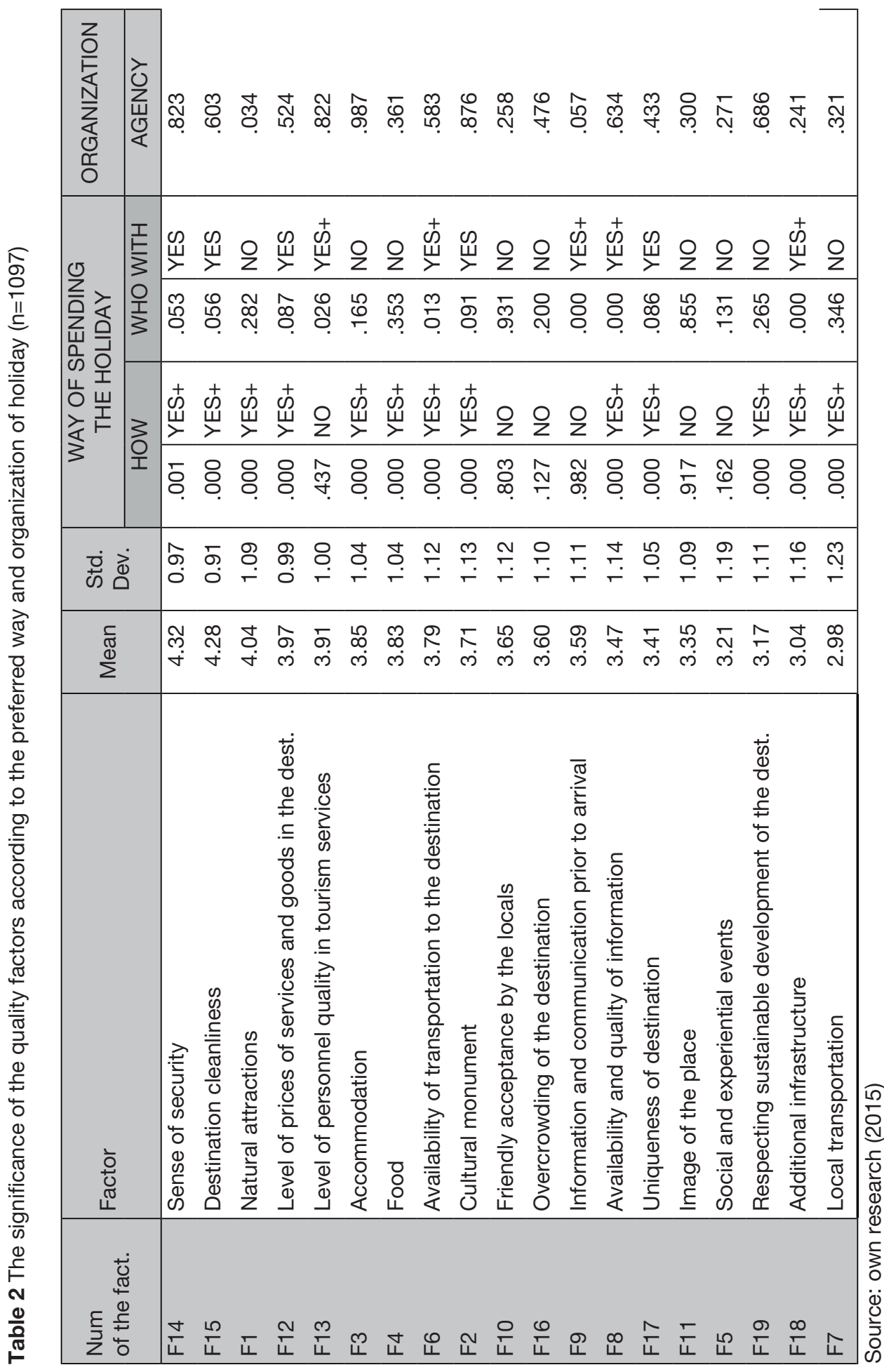




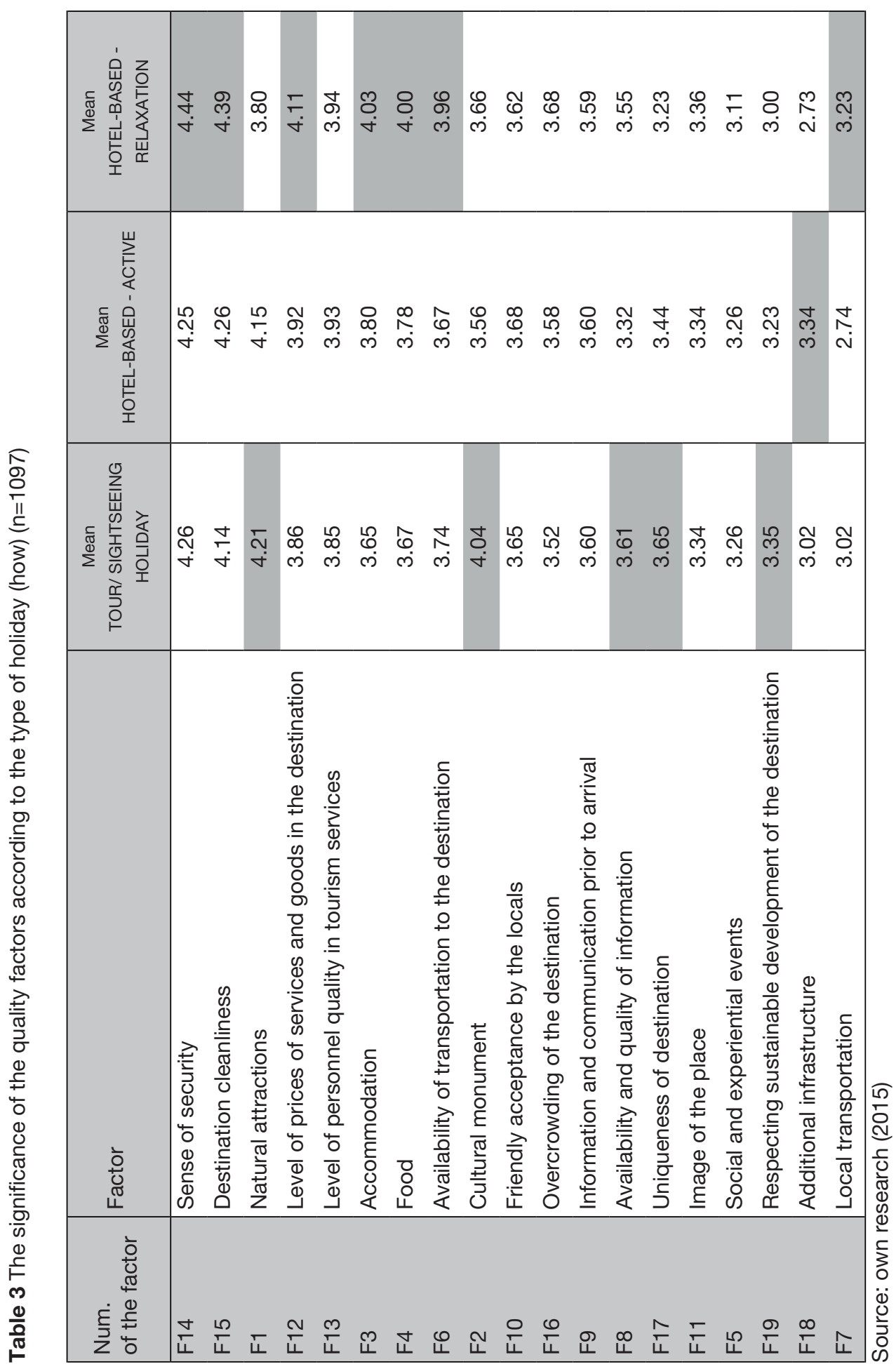


tive holiday. In spite of the fact that those people spend all their stays at one place, they want to spend them by resting actively, for which they probably need the additional infrastructure enabling them to spend their free time actively, e.g. doing sports activities.

Table 4 shows the perception of factor significance according to the preferred organization of holiday. In this category three groups of respondents were evaluated: respondents who use the services of travel agencies or tour operators when organizing their journey, respondents using the agent's services partly for partial journey elements only and finally, those who do not use tour operators' services. The results clearly show that the way of organizing the journey does not have any impact on the significance of the destination factors; in most cases the significance of the destination factors is inconclusive. This means that at present, in the times of information and communication technologies when a customer has an opportunity to obtain information and arrange his/her holiday almost all over the world even without using tour operators' services, the decision about using their services will not probably be related to the requirements for the destination quality but will rather be connected to the willingness, language and time possibilities to organize the holiday on one's own.

The dependency was proven in case of two evaluated quality factors only. The factor Natural attractions (e.g. mountains, water, caves) is the most appreciated by the respondents using tour operators' services only occasionally, which can be connected with the higher risk linked to extreme natural conditions, safety, a need for nonstandard equipment or the possibility of using a professional guide in the location where higher caution, knowledge and experience is required, e.g. in alpine, tropical or other risky environments. In other cases these clients are able to arrange the hotel-based or tour/ sightseeing holiday on their own. As expected, the factor Information and communication prior to arrival is appreciated the most by the people who organize their holiday fully on their own.

Table 5 below shows the significance of the quality factors according to the type of holiday, i.e., who the respondent spends his/her holiday with. In this question it was allowed to choose more answers. Therefore, there were many combinations of answers this question. To simplify the division, the criterion of whether the respondent spends his/her holiday with children was chosen as the most substantive. The respondents were divided into five categories: 1: without children, with a partner only; 2: without children, with friends only; 3: without children, with a partner as well as friends; 4: at least one child of a pre-school age; 5 : with school children only.

In more than the half of the quality factors (10 out of 19; F14, F15, F12, F13, F6, F2, F9, F8, F17, F18), the dependency of significance on the fact who the respondents spend their holiday with was proven on $10 \%$ significance level.

Almost all factors (9 out of 10) where the dependency is conclusive reached the highest score of evaluation for the subgroups with children. The highest importance is attributed to the Sense of security and Destination cleanliness, which corresponds to the presumptions of higher caution and responsibility when travelling with children. The factor Sense of security contains security issues of the destination, which includes not only the local security situation but also the security in the form of health risks (e.g. infectious 


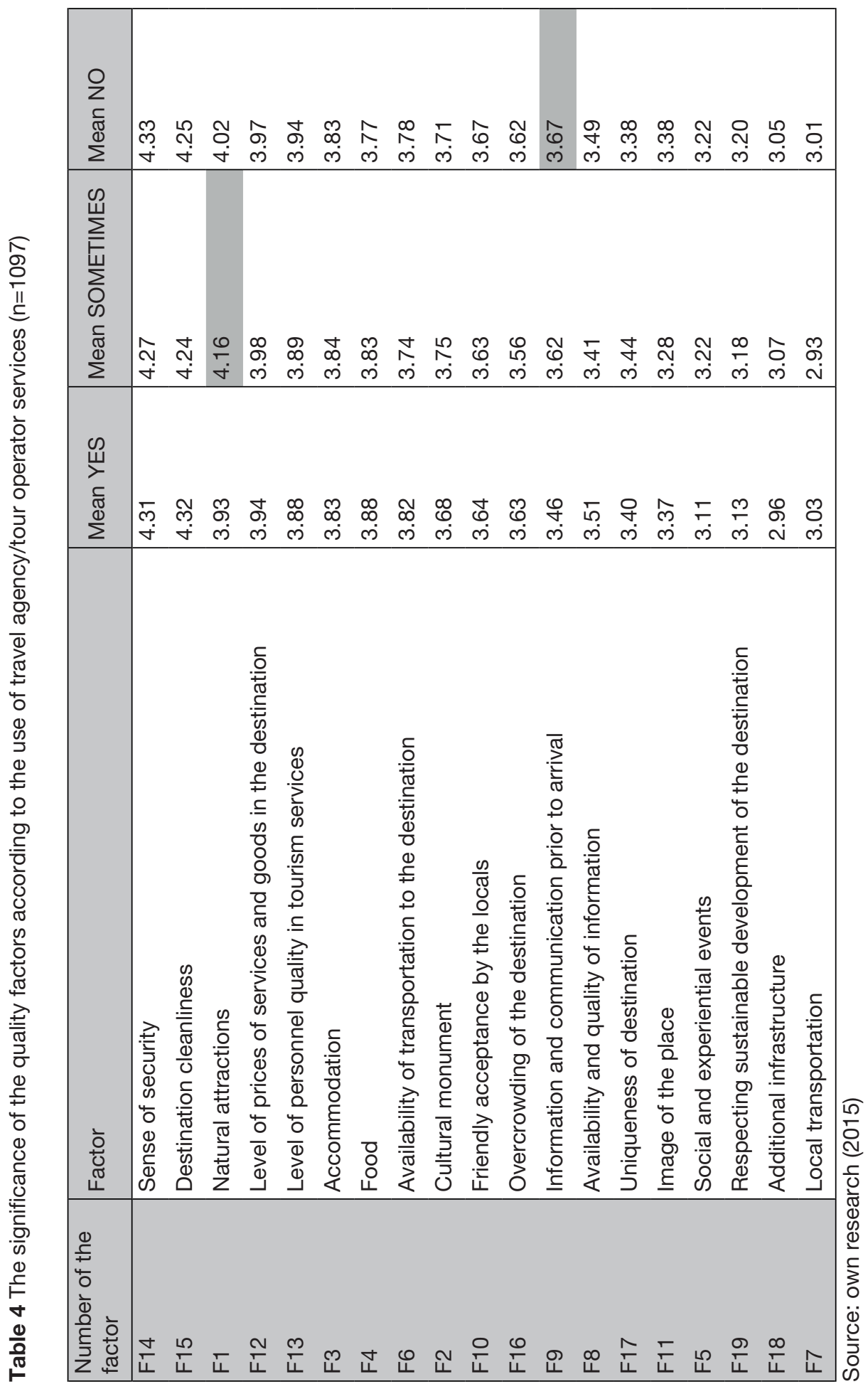




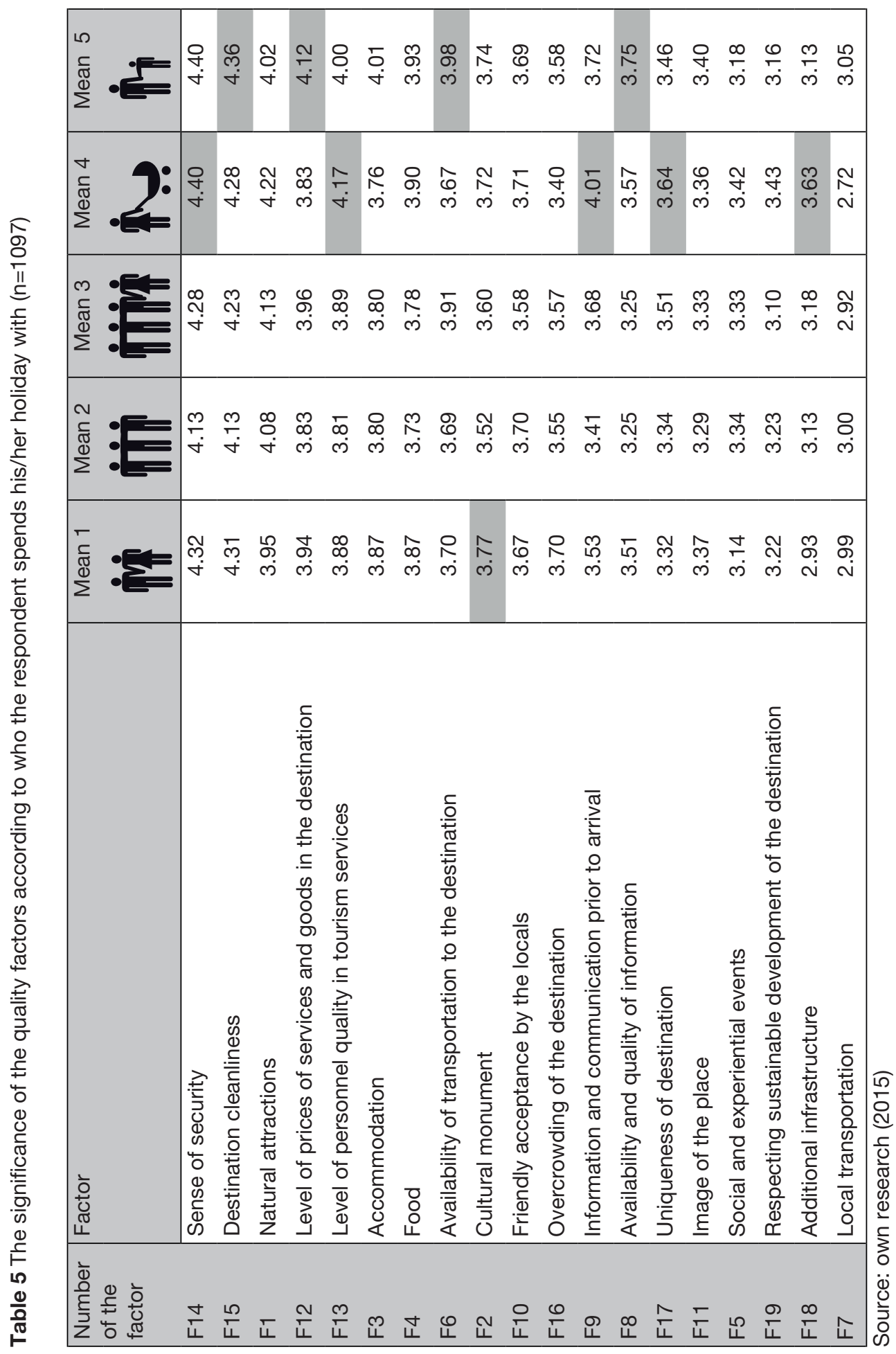


diseases, drinking water, and health system), safe natural conditions (e.g. earthquakes, floods), and the crime rate. The factor Destination cleanliness contains clean natural environment (water for swimming, air), way of dealing with local waste, cleanliness of public places, or urban cleanliness. The third place was taken by the factor level of prices of services and goods in the destination. This can be explained by higher demands on family budgets connected with bringing up and the provision of school children.

The lowest significance is assigned to the factor Additional infrastructure (e.g. sports equipment rental shops, cycle paths) where families with pre-school children do not look for these services due to their children's age. On the other hand, this factor Additional infrastructure was the only one to reach the highest score in case people preferred the hotel-based active holiday (see Table 3). It could be presumed that families with young children rather search for the hotel-based relaxation holiday. However, this presumption was not confirmed by Chi-quadrate test on the $10 \%$ significance level. Therefore, we can only suppose that people who prefer active ways of spending their holiday do not change their preferences very much even when they have children.

\section{Conclusion}

The tourism destination is a unit of competition and through the quality of its offerings it is struggling for the favour of visitors in the competitive environment. Tourism represents a very perspective part of many countries' economies. Therefore, it is important to pay more attention to this issue although as the literature review shows, there is no research on the evaluation of the destination quality as a complex product of tourism is missing. The existing research mostly focuses on the evaluation of service quality in sub-branches of tourism (e.g. Hsieh et al., 2008; Martin-Cejas, 2006; Zhu \& Zhao, 2010; Truong \& Foster, 2006; Chitty et al., 2007). In the Czech Republic the analysis of the factors affecting the development of tourism in the context of regional differentiation was more closely dealt with by Vystoupil and Šauer et al. (2011).

This paper summarizes the results of the partial research focused on the identification of the significant quality destination factors in relation to different groups of visitors according to their dissimilar behavioural characteristics and it is elaborated in the frame of a wider research project aimed to develop a methodology for the destination quality evaluation in the context of customer satisfaction and loyalty.

The most significant factors of destination quality for the residents of the Czech Republic are Sense of security and Destination cleanliness. Both of these factors were identically used in the study (Yoon \& Uysal, 2005) that examines pull motivations connected with the satisfaction and loyalty of the destination visitors. On the contrary, the least significant were Additional infrastructure and Local transportation factors.

The results presented above, together with the results of the dependence analysis of the visitors' perception of the destination quality on gender and age (Ryglova at al., 2015), are a significant source for further managerial decision-making processes. This is important both for service providers in the context of marketing mix design and for 
destination managers, especially those in the area of place image and communication with target groups. The dependence on gender was proven at the $5 \%$ significance level in case of 11 factors out of 19 (almost 60\%). Collins and Tisdell (2002) also confirmed gender differences in tourism but more from the point of reasons for the journey. The dependence on age was proven at the $5 \%$ significance level in case of 16 factors out of 19 (almost 85\%).

Quality is closely connected with customer satisfaction (Baker \& Crompton, 2000; Campo-Martãnez \& Garau-Vadell, 2010; de Rojas \& Camarero, 2008). In fact, it is the immediate reflection of a customer's satisfaction and therefore it can be successfully evaluated just according to his/her satisfaction. The factors of quality can also be used for the identification of strengths and weaknesses in destination quality management processes as a tool to measure the competitiveness of destinations in the Czech Republic or in the destinations of other countries disposing of similar conditions and presumptions for tourism. The revealed factors of quality can enter the quality evaluation models by using customer perspective and they can form an interesting base for their modification in case of important destination/regional differences.

The further research will contain the verification of the obtained results in different types of destinations (urban, rural, spa, mountain) and possibly, a suggestion of modification for individual types of destinations.

\section{Acknowledgements}

The results presented in this paper are part of the project No. 15-21179S „The Quality Evaluation of Tourism Destination “, which is conducted with support of Grant Agency of the Czech Republic.

\section{References}

Baker, D. A., \& Cropton, J. L. (2000). Quality, satisfaction and behavioral intentions. Annals of Tourism Research, 27(3), 785-804. DOI: 10.1016/S0160-7383(99)00108-5

Balogu, S., \& Uysal, M. (1996). Market segments of push and pull motivations: a canonical correlation approach. International Journal of Contemporary Hospitality Management, 8(3), 32-38.

Bieger, T. (1996). Management von Destinationen und Tourismusorganisationen. München: Oldenburg Verlag.

Buhalis, D. (2003). eTourism: information technology for Strategic Tourism Management. London: Prentice Hall.

Campo-Martãnez, P., \& Garau-Vadell, J. B. (2010). The generation of tourism destination satisfaction. Tourism Economics, 16(3), 461-475. DOI: 10.5367/000000010792278383

Chitty, B., Ward, S., \& Chua, A. C. (2007). AN application of the ECSI model as a predictor of satisfac-tion and loyalty for backpacker hostels. Marketing Intelligence, 25(6), 563-580. DOI: $10.1108 / 02634500710819941$

Cho, B. H. (2000). Destination. In J. Jafari (ed.), Encyklopedia of Tourism (pp. 144-145). Abingdon/ New York: Routledge.

Cohen, E. A (1979). Phenomenology of Tourist Experiences. Sociology, 13(2), 179-201.

Cohen, E. A. (1972). Towards a sociology of international tourism. Social Research, 39(1), 64-82. 
Collins, D., \& Tisdell, C. (2002). Gender and Differences in Travel Life Cycles. Journal of Travel Research, 41(2), 133-143. DOI: 10.1177/004728702237413

Crompton, J. L., \& Love, L. L. (1995). The predictive validity of alternative approaches to evaluating quality of festival. Journal of Travel Research, 34(1), 11-24. DOI: 10.1177/004728759503400102

De Rojas, C., \& Camarero, C. (2008). Visitors' experience, mood and satisfaction in a heritage context: Evidence from an interpretation centre. Tourism Management, 29(3), 525-537. DOI: $10.1016 /$ j.tourman.2007.06.004

Decrop, A., \& Snelders, D. (2005). A grounded typology of vacation decision-making. Tourism management, 26(2), 121-132. DOI: 10.1016/j.tourman.2003.11.011

Eklof, J., \& Westlund A. (1998). Customer Satisfaction Index and its Role in Quality Management. Total Quality Management, 9(1), 80-85. DOI: 10.1080/0954412988613

Firestone, J., \& Shelton, B. A. (1994). A comparison of women's and men's leisure time. Leisure Sciences, 16(1), 45-60. DOI: 10.1080/01490409409513216

Fodness, D. (1992). The impact of family life cycle on the vacation decision making process. Journal of Travel Research, 31(2), 8-13. DOI: 10.1177/004728759203100202

Fornell, C., Johnson, M. D., Anderson, E. W., Cha, J., \& Bryant, B. E. (1996). The American customer satisfaction index: Nature, purpose and findings. Journal of Marketing, 60(4), 7-18. DOI: $10.2307 / 1251898$

Grönroos, C. (2007). Service Management and Marketing: Customer Management in Service Competition. New York: John Wiley \& Sons.

Hill, N., Brierley, J., \& MacDougall, R. (2003). How to Measure Customer Satisfaction? Hampshire/Burlington: Gower.

Hsieh, L. F., Lin, L. H., \& Lin, Y. Y. (2008). A service quality measurement architecture for hot spring hotels in Taiwan. Tourism Management, 29(3), 429-438. DOI: 10.1016/j.tourman.2007.05.009

Hsieh, S., O’Leary, J. T., \& Morrison, A. M. (1992). Segmenting the International Travel Market by Activity. Tourism Management, 13(2), 209-223. DOI: 10.1016/0261-5177(92)90062-C

Hsieh, S., O'Leary, J. T., Morrison, A. M., \& Chiang, D. (1997). Travel decision pattern segmentation of pleasure travel. Journal of Vacation Marketing, 3(4), 289-302. DOI: $10.1177 / 135676679700300402$

Kozak, M., \& Rimmington, M. (2000). Tourist satisfaction with Mallorca, Spain, as an off-season holiday destination. Journal of Travel Research, 38(3), 260-269. DOI: 10.1177/004728750003800308

Kreštić, D. (2008). Index of Destination Attractiveness (IDA): a Tool for Measuring Attractiveness of Tourism destination. In $4^{\text {th }}$ International Conference "An Enterprise Odyssey: Tourism-Governance and Entrepreneurship”, June 11-14, 2008, Dubrownik. Proceedings. Zagreb: University of Zagreb.

Martilla, J. A., \& James. J. C. (1977). Importance-performance analysis. Journal of Marketing, 41(1), 77-79. DOI: $10.2307 / 1250495$

Martin-Cejas, R. R. (2006). Tourism service quality begins at the airport. Tourism Management, 27(5), 874-877. DOI: 10.1016/j.tourman.2005.05.005

Meng, F., Tepanon, Y. A., \& Uysal, M. (2008). Measuring tourist satisfaction by attribute and motiva-tion: The case of a nature-based resort. Journal of Vacation Marketing, 14(1), 41-56. DOI: $10.1177 / 1356766707084218$

Middleton, V. T. C., \& Clarke, J. R. (2001). Marketing in Travel and Tourism. Boston: ButterworthHeinemann.

Ministry of Regional development [MMR]. (2015). Statistiky cestovniho ruchu 2015 (Tourism Statistics 2015). Prague. Retrieved from http://www.mmr.cz/cs/Podpora-regionu-a-cestovni-ruch/ Cestovni-ruch/Statistiky-Analyzy/Statistiky-cestovniho-ruchu-2015 
Mottiar, Z., \& Quinn, B. (2003). Shaping leisure / tourism places, the role of holiday home owners. Leisure Studies, 22(2), 109-127. DOI: 10.1080/0261436032000061169

Otto, J. E., \& Ritchie, J. R. B. (1995). The service experience in tourism. Tourism Management, 17(3), 165-174. DOI: 10.1016/0261-5177(96)00003-9

Parasuraman, A., Zeithaml, V. A., \& Berry, L. L. (1988). SERVQUAL: A Multiple-Item Scale for Measuring Consumers Perception of Service Quality. Journal of Retailing, 64(1), 12-40.

Ryglova, K., Vajcnerova, I., Sacha, J., \& Stojarova, S. (2015). The Quality as a Competitive Factor of the Destination. Procedia Economics and Finance, 34(1), 550-556. DOI:10.1016/S22125671(15)01667-6

Šímová, J. (2009). Faktory vypovídající o chování klientů cestovního ruchu (Factors indicate the behaviour of tourism customers). Marketing E̋ komunikace, 19(1), 14-16.

Spreng, R. A., Mackenzie, S. B., \& Olsavsky B. W. (1996). A re-examination of the determinants of consumer satisfaction. Journal of Marketing, 60(3),15-22. DOI: 10.2307/1251839

Truong, T. H., \& Foster, D. (2006). Using HOLSAT to evaluate tourist satisfaction at destinations: The case of Australian holidaymakers in Vietnam. Tourism Management, 27(5), 842-855. DOI: 10.1016/j.tourman.2005.05.008

UNWTO Quality Support Committee. (2003). Quality in Tourism. Varadero, Cuba: UNWTO Quality Support Committee. Retrieved from http://sdt.unwto.org/en/content/quality-tourism.

Vondruška, R. (2006). Monitoring návštěvníků v turistických regionech ČR v létě 2005 (Monitoring of visitors in the tourist regions of the Czech Republic in summer 2005). In Konference na téma Podpora domácího cestowního ruchu, 13. ledna 2006, Brno (pp. 16-33.) (Conference on the issue of Domestic tourism support). Praha: Ministry for Regional Development. Retrieved from http://www.mmr.cz/getmedia/0f3e991c-b5af-46b9-9339-a51c5c89d2aa/Sbornik-KonferencePodpora-domaciho-cestovniho-ruc.pdf?ext=.pdf

Vystoupil, J., Šauer, M., et al. (2011). Geografie cestovního ruchu České republiky (Tourism geography of the Czech Republic). Plzeň: Aleš Čeněk.

Woods, M., \& Deegan, J. (2003). A Warm Welcome for destination quality brands: the example of the Pays Cathare region. International Journal of Tourism Research, 5(4), 269-282. DOI: 10.1002/ jtr. 436

Xielong, X. (2011). Service quality Measurement from Customer Perception Based on Services Science, Management and Engineering. Systems Engineering Procedia, 1(1), 337-343.

Yoon, Y., \& Uysal, M. (2005). An examination of the effects of motivation and satisfaction on destination loyalty: a structural model. Tourism Management, 26(1), 45-56. DOI: 10.1016/j.tourman.2003.08.016

Žabkar,V., Brenčič, M. M., \& Dmitrović, T. (2010). Modelling perceived quality, visitor satisfaction and behavioural intentions at the destination level. Tourism Management, 31(4), 537-546. DOI: 10.1016/j.tourman.2009.06.005

Zhu, X. I. A. N., \& Zhao, S. R. (2010). Research on Evaluation of Tourism Public Service from the Perspective of Tourist Satisfaction. In Proceedings of 2010 International Conference on Public Administration (6th), Volume I, $22^{\text {nd }}$ October 2010, Canberra (pp. 643-648). Chengdu: University of Electronic Science and Technology Press. 